\title{
Alternative Control of Alternaria Brown Spot in Tangerine
}

\author{
Antonio Manoel Da Silva Filho' ${ }^{1 *}{ }^{*}$, Élida Barbosa Corrêa1, Alisson Queiroz Moura1,3, \\ Juan Manuel Anda Rocabado ${ }^{4}$ \\ ${ }^{1}$ Phytopathology Laboratory of the State University from Paraiba (UEPB), Lagoa Seca, Brazil \\ ${ }^{2}$ Department of Agricultural Engineering, Federal University of Campina Grande (DEAG/UFCG), Campina Grande, Brazil \\ ${ }^{3}$ Center University Araras, Dr. Edmundo Ulson, Araras, Brazil \\ ${ }^{4}$ Laboratory of Electronic Microscopy, Federal University of the Recôncavo of Bahia (UFRB), Cruz das Almas, Brazil \\ Email: ^antonio.uepb@gmail.com, elida.uepb@gmail.com, alissonq8@gmail.com, quirito2000@yahoo.com.br
}

How to cite this paper: Da Silva Filho, A.M., Corrêa, É.B., Moura, A.Q. and Rocabado, J.M.A. (2020) Alternative Control of Alternaria Brown Spot in Tangerine. Agricultural Sciences, 11, 1217-1231. https://doi.org/10.4236/as.2020.1112080

Received: November 4, 2020

Accepted: December 22, 2020

Published: December 25, 2020

Copyright (c) 2020 by author(s) and Scientific Research Publishing Inc. This work is licensed under the Creative Commons Attribution International License (CC BY 4.0).

http://creativecommons.org/licenses/by/4.0/

\section{(c) (i) Open Access}

\begin{abstract}
Alternaria brown spot is considered the main disease of tangerines in the State of Paraiba. The objective of work was to evaluate vegetal tinctures from bitter melon (Momordica charantia) and guava (Psidium guajava) leaves, as an alternative control for Alternaria brown spot in tangerine. The effects of vegetal tinctures were tested in leaves and fruits (detached) of tangerine "Dancy" inoculated with tangerine pathotype of Alternaria alternata. The effect of tinctures on mycelium growth and spore germination of the pathogen was tested. Tinctures at $20 \%$ concentration promoted reduction of disease severity. A reduction of $80 \%$ in the diameter of leaf lesions was observed for bitter melon tinctures and $75.3 \%$ for guava tinctures. In fruits, the reduction was $48.4 \%$ (bitter melon tinctures) and $43.3 \%$ (guava tinctures). Guava tinctures, starting at a concentration of $5 \%$, inhibited $100 \%$ of mycelium growth of tangerine pathotype of $A$. alternata, while the use of bitter melon tinctures inhibited $100 \%$ of mycelium growth starting at a concentration of $10 \%$. The greater sensitivity to tinctures observed when these were added to the culture medium when compared to inoculation in leaves and fruits may be explained due to the higher exposition of the pathogen to the active principle when the vegetal tinctures were added to the culture medium, than when tinctures were sprayed over the vegetal surface in fruits and leaves. The number of germinated spores decreases $76.7 \%$ and $82 \%$ when using tinctures from guava and bitter melon (20\%). Tinctures from bitter melon and guava are potential tools for alternative management of the Alternaria brown spot in tangerine "Dancy".
\end{abstract}

\section{Keywords}

Alternaria alternata f. sp. citri, Momordica charantia, Psidium guajava, 
Vegetal Extracts, Vegetal Tinctures

\section{Introduction}

Brazil is the biggest citrus fruit production country in the world, with prominence to the Southeast region and the State of Sao Paulo as the major Brazilian citrus fruit producer [1]. In Brazil, the main producing regions in a decreasing order are the Southeast, South, Northeast, Central-West and North region [2].

Alternaria brown spot caused by the fungus Alternaria alternata pathotype tangerine is considered the main disease of tangerines in the State of Paraiba, Brazil [1] [3] [4]. The pathogen infects young leaves, fruits and branches causing necrotic lesions with a yellowish halo [5].

The common approach to disease control consists in the use of contact and systemic fungicides [4] [5]. The employment of such agro-toxics in the field selects resistant lineages of the pathogen against the chemical substances used, besides the environmental harm due to the accumulation of such residues [6].

Due to the potential and real damages caused by the use of agro-toxics, the development of alternative approaches and methods to plant disease management is required. Among these alternatives, the use of vegetal tinctures, extracts and oils may be potentially interesting. The use of such products is auspicious for plant disease control, especially when considering the fact that plants possess the ability to produce different secondary metabolites that may have direct antimicrobial activity and/or induce plant resistance [6].

Among the plants being tested to control plant pathogens, bitter melon and guava may be mentioned among plants having anti-microbial natural constituents. Bitter melon produces antimicrobial substances such as tannins, flavones, xanthones, flavanonols, leucanthocyanidins and catechins, found in the extracts of this plant [7]. Guava also produces antimicrobial substances such as flavonoids, steroids and tannins found in methanolic extracts of the plant [8].

Due to the requirement of an ecologically alternative to the management of the Alternaria brown spot, the objective of this work was to evaluate the control of the disease in tangerine "Dancy", using vegetal tinctures from leaves of bitter melon and guava.

\section{Materials and Methods}

\subsection{Inoculum Isolation and Preparation of Vegetal Tinctures}

Alternaria alternata pathotype tangerine was isolated from symptomatic fruits of tangerine "Dancy" in Petri dishes containing Potato Dextrose Agar (PDA) growth media at $25^{\circ} \mathrm{C}$ for seven days.

Vegetal tinctures were obtained after drying plant leaves at $60^{\circ} \mathrm{C}$ in oven. Dried leaves were milled. Vegetal tinctures were obtained after maceration of the dried milled leaves $(200 \mathrm{~g})$ in $70 \%$ ethyl alcohol $(800 \mathrm{~mL})$ at laboratory temper- 
ature for $48 \mathrm{~h}$. Tinctures were gauze filtered and stored in glass vials away from the sunlight.

\subsection{Evaluation of Tangerine Fruits}

Two experiments were performed in order to evaluate tinctures to preventive control of the disease in tangerine "Dancy" fruits: 1) evaluation of tinctures from leaves of bitter melon (Momordica charantia) and guava (Psidium guajava) at a concentration of $20 \%$ and 2) evaluation of tinctures at concentrations of $0 \%, 1 \%$, $5 \%, 10 \%$ and $20 \%$.

In the first experiment, healthy fruits of tangerine "Dancy" were washed in tap water and dried. Then treatments were applied on these fruits by spraying $26 \mathrm{~mL}$ of each tincture, separately. Then, fruits were wounded with the aid of a needle ( $3 \mathrm{~mm}$ depth) and a $4 \mathrm{~mm}$ diameter disc of the patogen's culture in BDA (seven days old) were placed over the wound. Separate fruits were set in open Petri dishes $(9 \mathrm{~cm})$ containing cotton moistened in distilled-sterilized water before being placed into plastic bags at room temperature $\left(25^{\circ} \mathrm{C} \pm 2{ }^{\circ} \mathrm{C}\right)$. Wound growth was evaluated $48 \mathrm{~h}, 96 \mathrm{~h}$ and $120 \mathrm{~h}$ after inoculation (hai). The first experiment was performed under a completely randomized design with five treatments: 1) bitter melon tincture, 2) guava's tincture, 3) inoculated control and 4) control without inoculation and four replicates.

In the second experiment the same methodology described was used but with ten replicates for each treatment, using tinctures from bitter melon and guava, independently. Different concentrations of the tinctures were used for the evaluation of different fungitoxic concentrations below the concentration of $20 \%$.

The following tincture concentrations were evaluated: 1) $1 \%$,2) 5\%, 3) $10 \%$, 4) $20 \%, 5)$ inoculated control and 6) non inoculated control. Disease severity was evaluated 48 hai. The period of 48 hours after inoculation was used to standardize the evaluation with the evaluation period of the leaves.

\subsection{Evaluation in Tangerine Leaves}

Two experiments were set to evaluate the preventive control of the disease in leaves of tangerine "Dancy" using vegetal tinctures from bitter melon and guava leaves. In the first experiment tinctures were evaluated at a $20 \%$ concentration, while in the second the concentrations of $0 \%, 1 \%, 5 \%, 10 \%$ and $20 \%$ were evaluated. In the first experiment, young healthy tangerine leaves were sprayed with $1 \mathrm{~mL}$ of each vegetal tincture, separately. Leaves from the inoculated and noninoculated control treatments were sprayed with distilled-sterilized water. After spraying leaves (placed in Petri dishes) the pathogen was inoculated using a culture media disc ( $4 \mathrm{~mm}$ diameter) on the surface of wounded leaves. To evaluate the different vegetal tincture concentrations $(0 \%, 1 \%, 5 \%, 10 \%$ and $20 \%)$ the same methodology described in the first experiment was used. The experiments were implemented under a completely randomized design with ten replicates. Leaves were set in Petri dishes in humid chamber at room temperature $\left(25^{\circ} \mathrm{C} \pm\right.$ 
$2^{\circ} \mathrm{C}$ ). In the first experiment the treatments tested were: 1) bitter melon tincture, 2) guava's tincture, 3) inoculated control and 4) non-inoculated control. In the second experiment tinctures were evaluated separately, testing tinctures with concentrations of: 1) $1 \%$, 2) $5 \%$, 3) $10 \%$, 4) $20 \%$, 5) inoculated control and 6) non-inoculated control. The length of the lesions was evaluated 48 hai.

\subsection{Evaluation of Mycelium Growth}

The evaluation of effect of tinctures over the pathogen's mycelium growth was performed in two experiments: 1) tinctures were tested at $20 \%$ concentration and 2 ) tinctures were tested at concentrations of $0 \%, 1 \%, 5 \%, 10 \%$ and $20 \%$. In experiment (1), tinctures from leaves from bitter melon and guava were added to PDA medium at a concentration of $20 \%$ in Petri dishes. Then, a $4 \mathrm{~mm}$ disc from each of the five pathogen's isolates, were placed in the center of the Petri dish separately. Mycelium growth of the isolates was evaluated after $48 \mathrm{~h}$ incubation at $25^{\circ} \mathrm{C} \pm 2{ }^{\circ} \mathrm{C}$. In experiment (2), concentrations of $1 \%, 5 \%, 10 \%$ and $20 \%$ of vegetal tinctures were tested, according methodology described for the first experiment, using only one isolate from $A$. alternata pathotype tangerine. Evaluations of mycelium growth were performed $96 \mathrm{~h}$ after transfer of mycelium, at the same incubation conditions. The experiments were completely random designed, with five replicates per treatment.

\subsection{Evaluation of Germination Inhibition}

In order to evaluate the ability to inhibit conidial germination of the pathogen, the method according Canihos [9] for spores' production was used. A. alternata pathotype tangerine conidia were collected after 7 days incubation in Petri dishes containing sporulation medium $\left(30 \mathrm{~g} \mathrm{CaCO}_{3}, 20 \mathrm{~g}\right.$ dextrose and $20 \mathrm{~g}$ agar per $1000 \mathrm{~mL}$ ). To collect conidia $5 \mathrm{~mL}$ of distilled and sterilized water were added to each Petri dish, slightly scratching colonies with the aid of a glass Drigalsky spatula. The conidial suspension was calibrated with the aid of a Neubauer chamber to a concentration of $2.4 \times 10^{5}$ spores $/ \mathrm{mL}$. The evaluation for germination inhibition by tinctures from leaves of guava and bitter melon in different concentrations $(1 \%, 5 \%, 10 \%, 15 \%$ and $20 \%)$ was performed in Kline dishes $(60 \times 80 \mathrm{~mm})$ filled with agar-water medium $(500 \mu \mathrm{l})$. Elisa plate was used to expose the suspension of conidia to the tinctures for 60 minutes. Then, $20 \mu \mathrm{l}$ of the suspension were simultaneously placed in the Kline dishes. Distilled autoclaved water was used as control. Kline plates were conditioned in Petri dishes at room temperature (maximum of $26^{\circ} \mathrm{C}$ and minimum of $20^{\circ} \mathrm{C}$ ) in the dark.

The experiment was performed under a completely randomized design with six replicates. Each tincture was evaluated in an experiment. The evaluation was done $24 \mathrm{~h}$ after deposition and incubation of the spores' suspension. The number of germinated spores, in a total of 100 spores was evaluated per replicate. A germinated spore was defined as one having the length of the germination tube longer that the spore's length. 
A variance analysis was used for quantitative data and the Shapiro-Wilk test was used to verify data normality, where the means were compared by the Tukey test at $5 \%$ probability. Relating quantitative data, the variables were analyzed in function of the tincture's concentration $(1 \%, 5 \%, 10 \%$ e $20 \%)$ by means of a polynomial regression. To the best fitting model the following criteria were adopted: significant regression $(\mathrm{p}<0.05)$, significant $\mathrm{t}$ test for all the parameters of the equation, determination coefficient and biological explanation. To compare tincture means regarding the control a Dunnett test at $5 \%$ probability was performed.

All statistical analysis were done with the aid of the software R' [10] and SigmaPlot 12.0 [11], using the last one to also obtain the graphics.

\section{Results and Discussion}

According results from variance analysis, the use of tinctures from bitter melon and guava leaves at $20 \%$ concentration had a significant effect over the lesion growth caused by $A$. alternata pathotype tangerine in fruits for all evaluated periods ( $48 \mathrm{~h}, 96 \mathrm{~h}$ and 120 hai). A growth reduction of $17.7 \%$ and $46.6 \%$ at 48 hai; $47.6 \%$ and $67.7 \%$ at 96 hai, $45.4 \%$ and $58.1 \%$ at 120 hai, were observed for bitter melon and guava tinctures, respectively (Figure 1(a)).

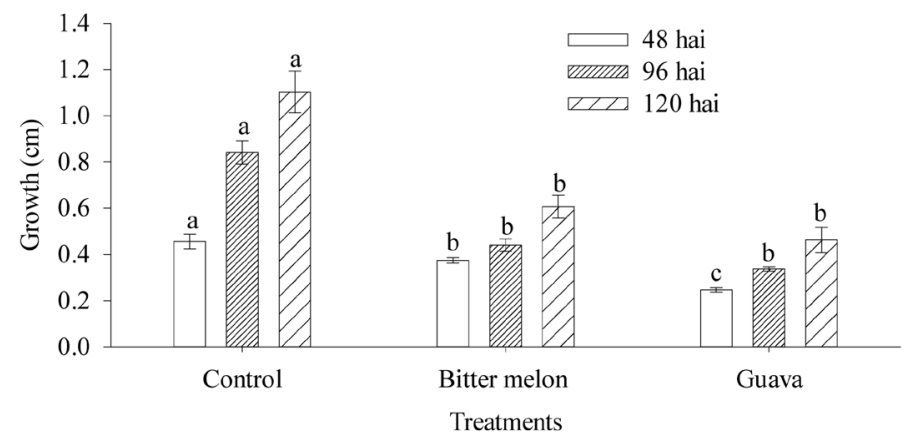

(a)

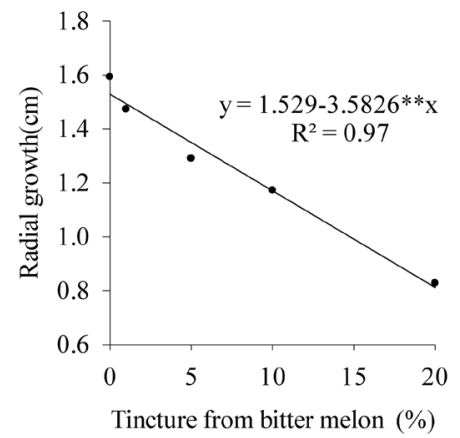

(b)

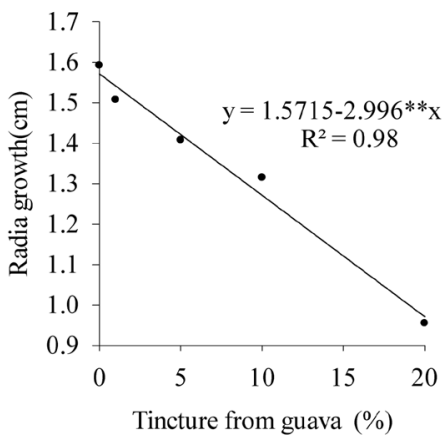

(c)

Figure 1. Effect of application of tinctures from guava and bitter melon leaves at $20 \%$ concentration (a), tincture from bitter melon at $0 \%, 1 \%, 5 \%, 10 \%$ and $20 \%$ concentration (b) and tincture from guava leaves at $0 \%, 1 \%, 5 \%, 10 \%$ and $20 \%$ (c) in the development of Alternaria brown spot $(\mathrm{cm})$ in fruits of tangerine "Dancy". Means followed by the same letter are not significantly different by the Tukey test at $5 \%$ probability. 
Use of increasing bitter melon tincture concentrations (5\%,10\%,15\%, and $20 \%)$ reduced the development of the radial growth lesion in fruits of tangerine "Dancy" (Figure 1(b)).

Evaluation of the effect of guava tincture's concentration on the disease, in tangerine fruits, showed a reduction of the radial growth of the lesion with the increasing concentration of the tincture (Figure $1(\mathrm{c})$ ).

Table 1 shows the results from radial growth of Alternaria brown spot in fruits of tangerine "Dancy" after treatment with different concentrations of bitter melon and guava leaves' tinctures. It is possible to observe that bitter melon and guava tinctures were effective in reducing radial growth of the disease only at a concentration of $20 \%$, with significant results at $\mathrm{p}<0.05$ with values inferior than control obtained by the Dunnett test (Table 1).

In tangerine leaves, the application of guava and bitter melon tinctures at a concentration of $20 \%$ reduced the development of the Alternaria brown spot in $1.2 \mathrm{~cm} \mathrm{(50 \% )} \mathrm{and} 1.41 \mathrm{~cm}$ (55\%), respectively, 48 hai, differing from the inoculated control (Figure 2(a)).

It was evidenced that for bitter melon and guava tinctures, only the concentration of $1 \%$ was not efficient to reduce radial growth of the disease in tangerine leaves, showing non-significant results $(\mathrm{p}<0.05)$ and lower values than the control by the Dunnett test, however they provided growth reduction.

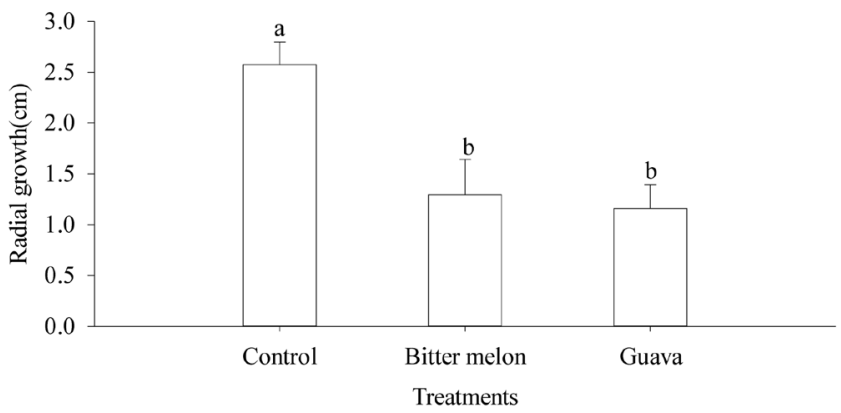

(a)

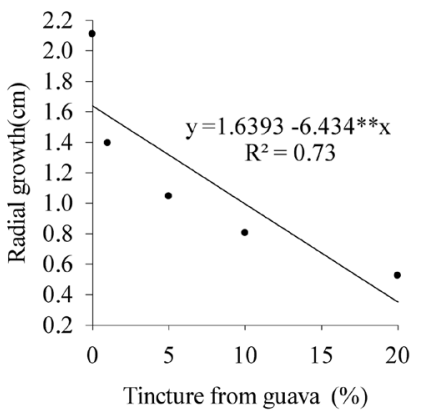

(b)

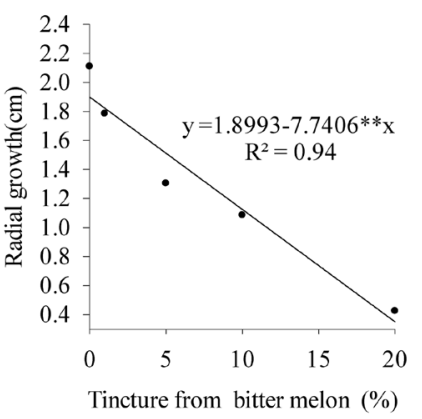

(c)

Figure 2. Effect of tinctures from bitter melon and guava, at a $20 \%$ concentration (a), tincture from guava leaves at concentrations of $0 \%, 1 \%, 5 \%, 10 \%$ and $20 \%$ (b) and tincture from bitter melon at concentrations of $0 \%, 1 \%, 5 \%, 10 \%$ and $20 \%$ (c), in the development of Alternaria brown spot (cm) on leaves of tangerine "Dancy". Means followed by the same letter are not significantly different by the Tukey test at $5 \%$ probability. 
Table 1. Radial growth $(\mathrm{cm})$ and inhibition percentage of Alternaria brown spot in fruits of tangerine "Dancy" treated with tinctures from bitter melon and guava leaves at concentrations of $1 \%, 5 \%, 10 \%$ and $20 \%$.

\begin{tabular}{ccccc}
\hline \multirow{2}{*}{ Treatments } & \multicolumn{2}{c}{ Bitter melon tincture } & \multicolumn{2}{c}{ Guava tincture } \\
\cline { 2 - 5 } & $\begin{array}{c}\text { Radial } \\
\text { growth }(\mathrm{cm})\end{array}$ & $\begin{array}{c}\text { Inhibition of } \\
\text { radial growth (\%) }\end{array}$ & $\begin{array}{c}\text { Radial } \\
\text { growth }(\mathrm{cm})\end{array}$ & $\begin{array}{c}\text { Inhibition of } \\
\text { radial growth }(\%)\end{array}$ \\
\hline Control (0\%) & 1.59 & 0 & 1.59 & 0 \\
$1 \%$ & $1.47^{\mathrm{ns}}$ & 7.5 & $1.51^{\mathrm{ns}}$ & 5.6 \\
$5 \%$ & $1.29^{\mathrm{ns}}$ & 18.8 & $1.41^{\mathrm{ns}}$ & 11.9 \\
$10 \%$ & $1.17^{\mathrm{ns}}$ & 26.41 & $1.32^{\mathrm{ns}}$ & 18.2 \\
$20 \%$ & $0.83^{*}$ & 48.42 & $0.96^{*}$ & 43.3 \\
\hline
\end{tabular}

${ }^{*}$ Significant and lower that the control by the Dunnett test at $5 \%$ probability; ns- Not significant by the Dunnett test at $5 \%$ probability.

On the contrary, concentrations of $5 \%, 10 \%$ and $20 \%$ promoted increasing reduction of the disease growth in leaves of tangerine, showing significant results $(\mathrm{p}<0.05)$ and lower values that the control by the Dunnett test (Table 2).

An increasing reduction of the lesion caused by $A$. alternata pathotype tangerine in leaves was observed with the increment in concentrations of the guava tinctures, with these data fitting to the decreasing linear regression model with a satisfactory prediction capability (Figure 2(b)). The increasing concentration of bitter melon leaf extract promoted a reduction of lesions caused by the pathogen in tangerine leaves, with data fitting to the decreasing linear regression model with high prediction capacity (Figure 2(c)).

A toxic effect was verified with the addition of tinctures of bitter melon and guava, at concentration of $20 \%$, to the culture medium, inhibiting $100 \%$ of the mycelium growth of isolates (Figure 3 ). When tinctures were added at different concentrations to the culture medium, an increment in growth reduction percentages was observed along with the increment in concentration of tinctures (Figure 3(b) and Figure 3(c)).

A significant effect on mycelium growth of $A$. alternata pathotype tangerine was verified from bitter melon and guava tinctures, at concentrations of $1 \%, 5 \%$, $10 \%$ and $20 \%$, when compared to the control $(0 \%)$ by the Dunnett test $(\mathrm{p}<0.05)$ (Table 3).

Higher effect was verified for guava tinctures, when inhibiting $41.8 \%$ of mycelium growth at a concentration of $1 \%$ and inhibiting $100 \%$ growth at a concentration of $5 \%$ (Table 3).

The increasing concentration of vegetal tinctures promoted higher control of the disease and inhibition of mycelium growth of the pathogen (Figure 1(b), Figure 1(c), Figure 2(b), Figure 2(c), Figure 3(b) and Figure 3(c)). However, it was observed a higher capacity for inhibiting the pathogen (Figure $3(b)$ and Figure $3(c)$ ), than the disease (Figure 1(b), Figure 1(c), Figure 2(b) and Figure $2(c))$. This effect may be explained by the higher concentration of the active 


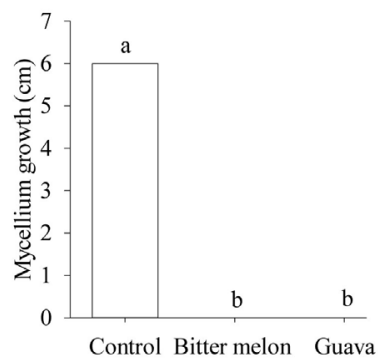

(a)

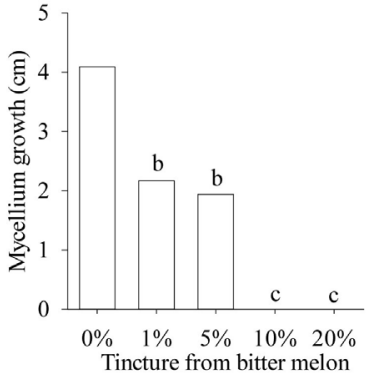

(b)

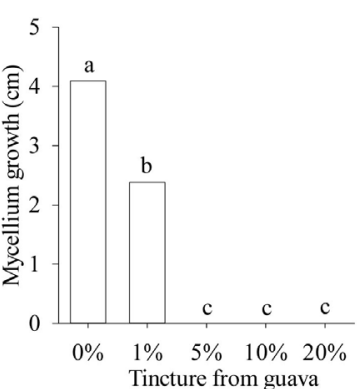

(c)

Figure 3. Effect of bitter melon and guava leave's tinctures, at a concentration of $20 \%$ (a), tincture of guava leaves at concentrations of $0 \%, 1 \%, 5 \%, 10 \%$ and $20 \%$ (b) and tincture of bitter melon at concentrations of $0 \%, 1 \%, 5 \%, 10 \%$ and $20 \%$ (c) on A. alternata pathotype tangerine mycelium growth in Petri dishes containing PDA medium. Means followed by the same letter are not significantly different by the Tukey test at $5 \%$ probability.

Table 2. Radial growth $(\mathrm{cm})$ and inhibition percentage of Alternaria brown spot on leaves of tangerine "Dancy" treated with tinctures of for bitter melon and guava ate concentrations of $1 \%, 5 \%, 10 \%$ and $20 \%$.

\begin{tabular}{ccccc}
\hline \multirow{2}{*}{ Treatments } & \multicolumn{2}{c}{ Bitter melon tincture } & \multicolumn{2}{c}{ Guava tincture } \\
\cline { 2 - 5 } & $\begin{array}{c}\text { Radial } \\
\text { growth }(\mathrm{cm})\end{array}$ & $\begin{array}{c}\text { Inhibition of } \\
\text { radial growth (\%) }\end{array}$ & $\begin{array}{c}\text { Radial } \\
\text { growth }(\mathrm{cm})\end{array}$ & $\begin{array}{c}\text { Inhibition of } \\
\text { radial growth }(\%)\end{array}$ \\
\hline Control (0\%) & 2.11 & 0 & 2.11 & 0 \\
$1 \%$ & $1.79^{\text {ns }}$ & 15.16 & $1.40^{\text {ns }}$ & 33.64 \\
$5 \%$ & $1.31^{*}$ & 37.91 & $1.05^{*}$ & 50.23 \\
$10 \%$ & $1.09^{*}$ & 48.34 & $0.81^{*}$ & 61.61 \\
$20 \%$ & $0.43^{*}$ & 79.62 & $0.53^{*}$ & 74.88 \\
\hline
\end{tabular}

* Significant and inferior to the control by the Dunnet test at $5 \%$ probability; ns- Not significant, by the Dunnet test at $5 \%$ probability.

Table 3. Mycelium growth $(\mathrm{cm})$ and inhibition percentage of Alternaria alternata pathotype tangerine in Petri dishes containing PDA medium, under effect of tinctures from leaves of Sao Caetano's bitter melon and guava, at concentrations of $1 \%, 5 \%, 10 \%$ and $20 \%$.

\begin{tabular}{ccccc}
\hline & \multicolumn{2}{c}{ Bitter melon tincture } & \multicolumn{2}{c}{ Guava tincture } \\
\cline { 2 - 5 } Treatments & $\begin{array}{c}\text { Mycelium } \\
\text { growth }(\mathrm{cm})\end{array}$ & $\begin{array}{c}\text { Growth } \\
\text { inhibition }(\%)\end{array}$ & $\begin{array}{c}\text { Mycelium } \\
\text { growth }(\mathrm{cm})\end{array}$ & $\begin{array}{c}\text { Growth } \\
\text { inhibition }(\%)\end{array}$ \\
\hline Control (0\%) & 4.09 & 0 & 4.09 & 0 \\
$1 \%$ & $2.17^{*}$ & 46.94 & $2.38^{*}$ & 1.8 \\
$5 \%$ & $1.94^{*}$ & 52.56 & $0^{*}$ & 100 \\
$10 \%$ & $0^{*}$ & 100 & $0^{*}$ & 100 \\
\hline
\end{tabular}

*Significant and inferior to the control by the Dunnet test at $5 \%$ probability. 
principle within the tinctures with the increase of their concentration, and by the higher exposition of the pathogen when the vegetal tinctures were added to the culture medium, than when tinctures were sprayed over the vegetal surface in fruits and leaves.

Different concentrations of tinctures from bitter melon and guava leaves reduced the number of germinated spores of the pathogen (Table 4). The increasing concentration of tinctures resulted in decreasing of the spores' germination; with the concentration of $20 \%$ resulting in higher reduction of spore germination, independently form the vegetal species that originated the tincture (Table 4).

The increase in concentration in guava tincture promoted accentuated reduction in the number of $A$. alternate pathotype tangerine. Mean values for this variable were best fitted to the simple linear model with high prediction capacity $\left(\mathrm{R}^{2}=0.97\right)$ (Figure $4(\mathrm{a})$ ). In the case of bitter melon tincture the number of germinated spores was lower, however the simple linear model showed good prediction capacity $\left(\mathrm{R}^{2}=0.80\right)$ (Figure $4(\mathrm{~b})$ ).

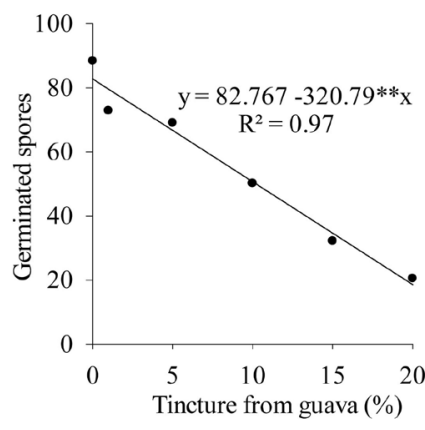

(a)

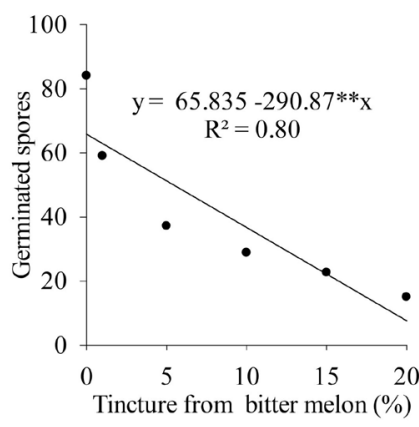

(b)

Figure 4. Effect of application of tinctures from guava leaves (a) and leaves from bitter melon (b) at concentrations of $1 \%, 5 \%, 10 \%, 15 \%$ and $20 \%$, on A. alternata pathotype tangerine spores germination in Kline plates containing agar-water medium.

Table 4. Germinated spores and germination percentage of Alternaria alternata pathotype tangerine in Kline plates containing agar-water added with different concentrations $(1 \%, 5 \%, 10 \%, 15 \%$ and $20 \%)$ of tinctures from bitter melon and guava leaves.

\begin{tabular}{ccccc}
\hline \multirow{2}{*}{ Treatments } & \multicolumn{2}{c}{ Bitter melon tincture } & \multicolumn{2}{c}{ Guava tincture } \\
\cline { 2 - 5 } & Germinated Spores & Germination & Germinated Spores & Germination \\
\hline Control (0\%) & 84.0 & 84.0 & 88.3 & 88.3 \\
$1 \%$ & $59.0^{* *}$ & 70.2 & $72.8^{\star *}$ & 82.7 \\
$5 \%$ & $37.1^{* *}$ & 44.2 & $69.0^{* *}$ & 78.4 \\
$10 \%$ & $28.8^{* *}$ & 34.3 & $50.1^{\star *}$ & 57.0 \\
$15 \%$ & $22.6^{* *}$ & 26.9 & $32.1^{\star *}$ & 36.5 \\
$20 \%$ & $15.0^{* *}$ & 17.8 & $20.5^{\star *}$ & 23.2 \\
\hline
\end{tabular}

${ }^{*}$ Significant and inferior to the control by the Dunnet test at $1 \%$ probability. 
Observing the results showed in Figure 4(a), reductions in the number of germinates spores of $17.5 \% ; 21.8 \% ; 43.2 \% ; 63.3 \%$ and $76.7 \%$ were verified when using guava leaves' tincture at concentrations of $1 \%, 5 \%, 10 \%, 15 \%$ and $20 \%$, respectively. Reduction in the number of germinated spores of $29.7 \%$; $55.8 \%$; $65.7 \% ; 73 \%$ and $82.1 \%$ was verified when using tincture from bitter melon at concentrations of $1 \%, 5 \%, 10 \%, 15 \%$ and $20 \%$, respectively.

According Schwan-Estrada [6] alcoholic or aqueous tinctures had showed potential to control plant pathogens, due to its direct fungitoxic activity inhibiting mycelium growth and germination of conidia, as well as by the induction of phytoalexins, showing the presence of compounds with characteristics of elicitors.

Gomes [7] while evaluating the chemical composition of bitter melon extracts, verified presence of compounds as tannins, flavones, flavonoids and xanthones, flavanonols, leucoanthocyanidins and catechines, that according [12], are part of the secondary metabolism of plants that mat have fungitoxic activity (direct antimicrobial effect), as well as being elicitors of defense mechanisms in plants (direct activity) and assist plants when they are exposed to biotic and abiotic stresses.

Control of $A$. alternata pathotype tangerine and Alternaria brown spot, with vegetal extracts from leaves, bark, flowers and stems from 105 species on tangor "Murcott" were evaluated by Carvalho [13]. The authors verified that application of angico (Anadenanthera colubrina) extract controlled the pathogen in vitro and the disease, with an equivalent control of Alternaria brown spot to fungicidal application. As previously observed by Carvalho [13], in the present work, vegetal tinctures from bitter melon and guava controlled the pathogen and the disease in vitro (Figures 1-3).

The potential of the vegetal extract from bitter melon to control plant pathogens and plant diseases has being studied by different authors [14] [15] [16]. Anti-viral, anti-bacterial and anti-fungal activity for this plant species were reported by Jayasinha [17]. Leaves of bitter melon contain alkaloids (mormodicin) [17], exhibiting anti-fungal activity against Colletotrichum gloeosporioides and Cladosporium cucumerium [18]. Antimicrobial substances were identified in extracts from $M$. charantia [19] [20] [21]. Isolated a terpenoid from the extract of $M$. charantia with chemical structure $3 \beta, 7 \beta, 25$-trihydroxycucurbita-5,23( $E)$ dien-19-al [19]. Isolated different triterpenoids as 25 -methoxy-3 $\beta, 7 \beta$ - dihydroxycucurbita-5,23(E)-dien-19-al, (23S)-3 $\beta$-hidroxy-7 $\beta, 23$-imethoxycucurbita-

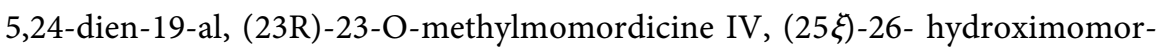
dicoside L, 25-oxi-27-normomordicoside $\mathrm{L}$ and 25-o-methylkaravilagenin D (12) [20]. Isolated eight triterpenoids from $M$. charantia: 1) $5 \beta$, 19-epoxy-19(R)methoxycucurbita-6, 23(E), 25-trien-3 $\beta$-ol (RA2-8); 2) $5 \beta$, 19-epoxy-25- methoxycucurbita-6, 23(E)-dien-3 $\beta$-ol (EMCDO); 3) (23E)-7 $\beta$, 25- dimethoxycucurbita-6, 23(E)-dien-3 $\beta$-ol (RA2-11); 4) $5 \beta$, 19-epoxi-19(S)-methoxycucurbita6,23(E)-dien-3 $\beta$, 25-diol (RA2-20); 5) (23E)-3 $\beta$-hydroxy-7 $\beta$, 25- dimethoxycur- 
bita-5,23-dien-19-al (RA2-52); 6) 5 $\beta$, 19-epoxyi-19(S), 25-dimethoxycucurbita6,23(E)-diene-3 $\beta$-diol (RA2-117); 7) (23E)-7 $\beta$-methoxicucurbita-6,23(E)-diene$3 \beta$, 25-diol (RA2-289) and 8 ) (23E)-3 $\beta, 7 \beta, 25$-trihydroxicurbita-5,23-dien- 19-al (CH93) [21]. In general, these terpenoids protect plants against fungi, bacteria and herbivores, promote germination of seeds [22], participate in vegetal growth through hormones [23], being commonly denominated as cucurbitacins [24].

According Colturato [25] the fungicides used to control tangerine alternate spot are pyraclostrobin and trifloxystrobin, both having in their formulation the radicals methyl and methoxy found in the structures from terpenoids identified in $M$. charantia [19] [20] [21]. The treatment with the fungicides pyraclostrobin and trifloxystrobin are efficient to control the disease, since the losses caused by the disease are less than 50\% compared to the control treatment [25]. Marigoni [26] verified the efficacy of the pyraclostrobin fungicide in controlling Alternaria in carrot leaves, with an area under the disease progress curve (AACPD) being found in 41.92 when treated with pyraclostrobin and 89.09 without any treatment (control), which resulted in a larger area to perform photosynthesis, consequently greater production and translocation of carbohydrates, thus showing greater weight of the roots when treated with pyraclostrobin. Tofoli [27] found that the fungicide pyraclostrobin + methiram inhibited $100 \%$ of conidia production and up to $80.4 \%$ of mycelial growth of Alternaria solani. Chitolina [28] studying the effect of the pyraclostrobin fungicide on the germination of 100 isolates of $A$. alternata and on the incidence of the disease in tangor Murcott tangerine leaves, found that the fungicide inhibits up to $100 \%$ the germination of conidia and reduces $100 \%$ the disease incidence. These radicals, methyl and methoxy present in the structures of triterpenoids promote a general dysfunction of the cell of $A$. alternata, inhibiting the germination of spores and appressoria in up to $82 \%$. Thus, the melon-São-Caetano tincture used in this work in different concentrations possibly made these substances available for the control of the disease in fruits and leaves, as well as promoting fungitoxity.

Fungitoxic effect of $P$. guajava was also verified by [29], while evaluating the effect of essential oils from Lippia sidoides, Ocimum gratissimum, Lippia citriodora, Cymbopogon citratus and Psidium guajava var. pomifera against $C$. gloeosporiodes (isolated form yellow passion fruit), and verifying inhibition of conidial germination and mycelium growth of the pathogen.

Dhiman [8] verified bacteriostatic and fungistatic effect from the methanolic vegetal extracts from guava leaves, and observed the presence of antiomicrobial compounds as flavonoids, steroids and tannins in the extracts, that may contribute to the antimicrobial effect of $P$. guajava. Similarly [30], verified the presence of saponins, different terpenoids and benzaldehyde in the hydroethanolic extract from guava, which according [31] are considered antimicrobial substances. Terpenoids protect plants against fungi, bacteria and herbivores [22]. Benzaldehyde is also an important substance, once it has exhibit cellular toxicity against $A s$ pergillus ninger, Ralstonia solani, Laetiporus sulphureus, Coriolus versicolor and 
Candida albicans when applied isolated, as well as when used in the form of vegetal extract or essential oil [32]. These secondary metabolites hold high degree of toxicity which promotes fungitoxic effect [33]. Furthermore, benzaldehyde is a substance used in the formulation of the trifloxystrobin, which according [25] is used to control Alternaria brown spot.

The probable presence of secondary metabolites produced by $P$. guajava, as saponins, terpenoids and benzaldehyde in the tinctures, may have been responsible by the control of the disease and fungitoxicity exhibited against $A$. alternata pathotype tangerine.

Currently, the main control strategy for Alternaria brown spot in tangerine consists in the use of systemic and contact fungicides, during the period of susceptibility of about four months after flowering [4] [5]. Truthfully, the extensive use of synthetic agrotoxics is constantly increasing the quantity of residues in fruits of tangerine, besides exerting high selection pressure over the pathogen. New control strategies against Alternaria brown spot, allied to cultural control management are required for the society, resulting in higher quality of tangerine fruits and lower environmental impact.

\section{Conclusions}

The use of vegetal tinctures from bitter melon and guava leaves reduces the size of Alternaria brown spots in detached fruits and leaves from tangerine "Dancy".

Vegetal tinctures from bitter melon and guava inhibit growth and germination of conidia from $A$. alternate pathotype tangerine.

Vegetal tincture concentrations of $20 \%$ are effective to control the disease in detached fruits and leaves.

\section{Acknowledgements}

To the State University from Paraíba (UEPB), by the under graduation scholarship and, to the agricultural and laboratory technician Yuri Mendes, for his assistance during this research.

\section{Conflicts of Interest}

The authors declare no conflicts of interest regarding the publication of this paper.

\section{References}

[1] Food and Agriculture Organization of the United Nations (2020) Citrus Fruit. http://www.fao.org/economic/est/est-commodities/citrus-fruit/en/

[2] Demartelaere, A.C.F., Nascimento, L.C., Abraão, P.C., Gomes, R.S.S.G., Marinho, C.O. and Nunes, M.C. (2018) Alternativas No Controle da Mancha Marrom de Alternaria em Tangerina “Dancy”. Summa Phyopatthological, 44, 164-169. https://doi.org/10.1590/0100-5405/173580

[3] Governo da Paraíba (2011). Paraíba Aumenta Produção de Tangerina e Ganha 
Mercado em Outros Estados. http://antigo.paraiba.pb.gov.br/index-56426.html

[4] Lopes, E.B., Albuquerque, I.C. and Araújo E. (2009) Mancha-Marrom-de-Alternaria: Uma Grave Doença nos Pomares de Tangerina da Paraíba. Tecnologia \& Ciência Agropecuária, 3, 23-27.

[5] Spósito, M.B., Júnior, J.B., Bassanezi, R.B. and Yamamoto P.T. (2003) Risco Marrom. Revista Cultivar Hortaliças e Frutas, 19, 22-35.

[6] Schwan-Estrada, K.R.F. (2009) Extratos Vegetais e de Cogumelos no Controle de Doenças de Plantas. Horticultura Brasileira, 27, 4038-4045.

[7] Gomes, R.V.R.S., Vilela V.L.R., Gomes E.N., Maia A.J. and Athayde A.C.R. (2011) Análise Fitoquímica de Extratos Botânicos Utilizados No Tratamento de Helmintoses Gastrintestinais de Pequenos Ruminantes. Revista Caatinga, 24, 172-177.

[8] Dhiman, A., Nanda, A., Ahmad, S. and Narasimhan, B. (2011) In Vitro Antimicrobial Activity of Methanolic Leaf Extract of Psidium guajava L. Jornal of Pharmacy \& Bioallied Science, 3, 226-229. https://doi.org/10.4103/0975-7406.80776

[9] Canihos, Y., Peever, T.L. and Timmer, L.W. (1999) Temperature, Leaf Wetness, and Isolate Effects on Infection of Minneola Tangelo Leaves by Alternaria sp. Plant Disease, 83, 429-433. https://doi.org/10.1094/PDIS.1999.83.5.429

[10] R Core Team (2013) R: A Language and Environment for Statistical Computing. R Foundation for Statistical Computing, Vienna.

[11] SigmaPlot (2012) SigmaPlot 12 for Windows Version 11.0. Statistics for User's Guide. Systat Software Inc., 578 p, Chicago.

[12] Stangarlin, J.R., Kuhn, O.J., Toledo, M.V., Portz, R.L., Schwan-Estrada, K.R.F. and Pascholati, S.F. (2011) A Defesa Vegetal Contra Fitopatógenos. Scientia Agraria Paranaenis, 10, 18-46.

[13] Carvalho, D.D.C., Camargos, R.B., Oliveira, D.F., Scolforo, J.R.S., Carvalho, D.A. and Batista, T.R.S. (2011) Plant Extracts to Control Alternaria alternata in Murcott Tangor Fruits. Revista Iberoamericana de Micología, 28, 173-178. https://doi.org/10.1016/j.riam.2011.05.001

[14] Araújo, A.K.O., Nascimento, L.C., Souza, W.J.S., Medeiros, J.G., Souza, W. and Araújo, A.C. (2012) Tratamento Alternativo No Controle de Fungos Associados a Sementes de Enterolobium contortisiliquum. Cadernos de Agroecologia, 8, 1-4.

[15] Silva, J.G., Melo, R.P., Araújo, J.D.M., Pessoa, M.N.G., Albiero, D. and Monteiro L.A. (2011) Avaliação de Extrato de Melão-de-são-Caetano (Momordica charantia L.) Como Medida Alternativa de Controle de Fungos Fitopatogênicos. Cadernos de Agroecologia, 6, 1-4.

[16] Celoto, M.I.B., Papa, M.F.S., Sacramento, L.V.S. and Celoto F.J. (2011) Atividade Antifúngica de Extratos de Momordica charantia L. Sobre Colletotrichum musae. Revista Brasileira de Plantas Medicinais, 13, 337-341. https://doi.org/10.1590/S1516-05722011000300013

[17] Jayasinha, P. (1999) Karawila (Momordica charantia). Medicinal and Aromatic Plant Series, 3, 1-36.

[18] Chandravadana, M.V., Nirdiry E.S.J. and Venkateshwarlu G. (1997) Antifungal Activity of Momordicines from Momordica charantia. Fitoterapia, 68, 383-384.

[19] Keller, A.C., MA, J., Kavalier, A., He, K., Brillantes, A.M.B. and Kennelly, E.J. (2011) Saponins from the Traditional Medicinal Plant Momordica charantia Stimulate Insulin Secretion in Vitro. Phytomedicine, 19, 32-37. 
https://doi.org/10.1016/j.phymed.2011.06.019

[20] Zhang, J., Huang, Y., Kikuchi, T., Tokuda, H., Suzuki, N., Inafuku, K., Miura, M., Motohashi, S., Suzuki, T. and Akihisa, T. (2012) Cucurbitane Triterpenoids from the Leaves of Momordica charantia, and Their Cancer Chemopreventive Effects and Cytotoxicities. Chemistry Biodiversity, 9, 428-440. https://doi.org/10.1002/cbdv.201100142

[21] Chang, C.I., Chen, C.R., Chen, Y.C., Cheng, K.W., Lin, B.W., Liao, Y.W. and Shih, W.L. (2015) Suppression of Hepatitis B Virus Production and Inflammatory Response in Vitro and in Vivo by Mormodica charantia Compound EMCDO. Journal of Agricultural Science, 7, 112-128. https://doi.org/10.5539/jas.v7n4p112

[22] Holetz, F.B., Pessini, G.L., Sanches, N.R., Cortez, D.A.G., Nakamura, C.V. and Dias Filho, B.P. (2002) Screening of Some Plants Used in the Brazilian Folk Medicine for the Treatment of Infectious Diseases. Memórias do Instituto Oswaldo Cruz, 97, 1027-1031. https://doi.org/10.1590/S0074-02762002000700017

[23] Morita, M., Shibuya, M., Kushiro, T., Masuda, K. and Yutaka E. (2000) Molecular Cloning and Functional Expression of Triterpene synthases from pea (Pisum sativum). European Journal of Biochemistry, 267, 3453-3460. https://doi.org/10.1046/j.1432-1327.2000.01357.x

[24] Marques, M.C.S. (2001) Estudo de Plantas Medicinais do Cerrado em Busca de Substâncias Bioativas e o Potencial Anti-Leishmania de Momordica charantia Linn. Thesis, Federal University of Mato Grosso of Sul, Brazil.

[25] Colturato, A.B., Paulossi, T., Venâncio, W.S. and Furtado, E.L. (2009) Efficiency and Cost of Chemical Control of Alternaria Brown Spot. Summa Phytopathologica 35, 210-215. https://doi.org/10.1590/S0100-54052009000300008

[26] Marigoni, A.C., Baldini, L.F.G., Demant, L.A.R., Evangelista, R.M. and Fujita, E. (2012) Ação de Fungicidas No Controle da Queima das Folhas e nas Características Físico-Química da Cenoura Cv. Nantes. Revista Brasileira de Produtos Agroindustriais, 14, 161-165. http://dx.doi.org/10.15871/1517-8595/rbpa.v14n2p161-165

[27] Tofoli, J.G., Domingues, R.J. and Kurozawa, C. (2003) Ação “in Vitro” de Fungicidas no Crescimento Micelial e Germinação de Conídios de Alternaria solani, Agente Causal da Pinta Preta do Tomateiro. Arquivos do Instituto Biológico, 70, 337-345.

[28] Chitolina, G.M. (2019) Caracterização da Sensibilidade de Alternaria alternata, Agente Causal da Mancha Marrom em Tangerinas, a Fungicidas Inibidores da Quinona Externa. Thesis, University of São Paulo, Higher School "Luiz de Queiroz".

[29] Souza, Jr., I.T., Sales, N.L.P. and Martins, E.R. (2009) Efeito Fungitóxico de óleos Essenciais Sobre Colletotrichum gloeosporioides, Isolado do Maracujazeiro Amarelo. Revista Biotemas, 22, 77-83.

[30] Silva, I.C.A., Aleixo A.A., Aleixo A.M., Figueiredo A.P., Lemuchi M.O. and Lima L.A.R.S. (2013) Análise fitoquímica e atividade antioxidante do extrato hidroetanólico das folhas de Psidium guajava L. (Goiabeira). Biochemistry and Biotechnology Reports, 2, 76-78. http://dx.doi.org/10.5433/2316-5200.2013v2n2espp76

[31] Fernandes, B.F., Gonçalves, H.R., Guimarães, M.R., Alves, A.A. and Bieski, I.G.C. (2019) Estudo Etnofarmacológico das Plantas Medicinais com Presença de Saponinas e sua Importância Medicinal. Revista da Saúde da AJES, 5, 16-22. 
[32] Pimentel, F.A., Cardoso, M.G., Batista, L.R., Guimaraes, L.G.L. and Silva, D.M. (2010) Ação Fungitóxica do óleo Essencial de Tanaecium nocturnum (Barb. Rodr.) Bur. e K. Shum Sobre o Aspergillus flavus Isolado da Castanha-do-Brasil (Bertholletia excelsa). Acta Amazônia, 40, 213-220. https://doi.org/10.1590/S0044-59672010000100027

[33] Darling, C., Schoroeder, F., Meinwald, J., Eisner, M. and Eisner, T. (2001) Production of a Cyanogenic Secretion by a Thyridid Caterpillar (Calindoea trifascialis, Thyrididae, Lepdoptera). Naturwissenschaften, 88, 306-309.

https://doi.org/10.1007/s001140100238 